\title{
Author Correction: Intranasal drug delivery of small interfering RNA targeting Beclin1 encapsulated with polyethylenimine (PEI) in mouse brain to achieve HIV attenuation
}

\author{
Myosotys Rodriguez ${ }^{1}$, Jessica Lapierre ${ }^{1}$, Chet Raj Ojha ${ }^{1}$, Ajeet Kaushik ${ }^{1}$, Elena Batrakova ${ }^{2}$, \\ Fatah Kashanchi ${ }^{3}$, Seth M. Dever ${ }^{1}$, Madhavan Nair ${ }^{1}$ \& Nazira El-Hage ${ }^{1}$
}

Correction to: Scientific Reports https://doi.org/10.1038/s41598-017-01819-9, published online 12 May 2017

This Article contains typographical errors in the Acknowledgements section.

"We gratefully acknowledge the support of the National Institutes of Health (NIH)-National Institute on Drug Abuse (NIDA) grants R01 DA036154; R21 DA041287 to NEH and DA041749 to MN and National Institutes of Health (NIH)-National Institute on Mental Health (NIMH) R01 MH110262 to FK."

should read:

"We gratefully acknowledge the support of the National Institutes of Health (NIH)-National Institute on Drug Abuse (NIDA) grants R01 DA036154; R21 DA041287 to NEH and DA034547 to MN and National Institutes of Health (NIH)-National Institute on Mental Health (NIMH) R01 MH110262 to FK.'

(c) (i) Open Access This article is licensed under a Creative Commons Attribution 4.0 International License, which permits use, sharing, adaptation, distribution and reproduction in any medium or format, as long as you give appropriate credit to the original author(s) and the source, provide a link to the Creative Commons license, and indicate if changes were made. The images or other third party material in this article are included in the article's Creative Commons license, unless indicated otherwise in a credit line to the material. If material is not included in the article's Creative Commons license and your intended use is not permitted by statutory regulation or exceeds the permitted use, you will need to obtain permission directly from the copyright holder. To view a copy of this license, visit http://creativecommons.org/licenses/by/4.0/.

(C) The Author(s) 2018

\footnotetext{
${ }^{1}$ Department of Immunology, Florida International University, Herbert Wertheim College of Medicine, Miami, FL, 33199, USA. ${ }^{2}$ University of North Carolina, Eshelman School of Pharmacy, Chapel Hill, NC, 27599, USA. ${ }^{3}$ Laboratory of Molecular Virology, School of Systems Biology, George Mason University, Manassas, VA, 20110, USA. Correspondence and requests for materials should be addressed to N.E.-H. (email: nelhage@fiu.edu)
} 